\title{
Conceptualizing Corruption in Public Private Partnerships
}

\author{
Rahel M. Schomaker ${ }^{1,2}$ \\ Published online: 5 March 2020 \\ (C) The Author(s) 2020
}

\begin{abstract}
This article conceptualizes the vulnerability of the different stages of Public-Private Partnership (PPP) models for corruption against the backdrop of contract theory, principal-agent theory and transaction cost economics, and discusses potential control mechanisms. The article's contribution to the debate on PPPs is twofold: first, an issue widely neglected by the pertinent literature is conceptualized. Second, as these PPPs are used not only in developed countries whose legal order may shield them sufficiently, but also in developing countries, carving out the vulnerable points in PPP arrangements may enable decision makers to install appropriate control mechanisms, if need be on project level.
\end{abstract}

Keywords Public private partnership · Corruption

\section{Introduction}

Cooperations between the public sector and private enterprises, so-called Public Private Partnerships (PPPs), have some historical pedigree supplementing or replacing the „traditional "governmental responsibility to provide and/or produce services of general economic interest, in particular in infrastructure. Nonetheless, as every kind of private sector participation, PPPs are instruments that pose challenges on the public administration (Farazmand 1999, 2002). This is all the more true considering the fact that "with sweeping privatization of public enterprises and other major governmental functions, the capacity and ability of governments in public management are seriously diminished" (Farazmand 1999, p. 152). These cooperation models, being very different in design and form, in general have to balance between the managerial autonomy of the

Rahel M. Schomaker

Rahel.Schomaker@online.de

1 CUAS, Europastraße 4, Villach, Austria

2 German Research Institute for Public Administration, Speyer, Germany 
private partner and democratic accountability of the public body involved. They are characterized by horizontal relations and shared responsibilities between the partners (Hodge 2006; Mörth 2009). They therewith epitomize the fact that the cutting lines between the public and private sphere are blurring and have to be re-evaluated.

Overall, PPPs are designed to raise potentials for a - quantitative and qualitative improvement of public services due to enhanced financial, managerial or technical efficiency (Klitgaard 2012; Kwak et al. 2009). Having an "iconic status around the world" (Hodge and Greve 2010, p. 8), they are often viewed as a sophisticated and professional alternative for modern infrastructure management. This promise as well as optimism from PPP advocates in many cases did not fully realize. The reasons can be endogeneous to the design of a single project, or more general exogeneous factors in the execution process of PPPs (for examples e.g. Hodge and Greve 2007). Several weaknesses could be mentioned here, as e.g. deal complexity, the need for long-term equity or problems related to the calculation of public sector costs (Hodge 2006).

Even if the process of PPP implementation and execution seems to be comparable to agreements on other forms of shared responsibilities between the public and the private sector, there are relevant differences, in particular regarding contract duration and design as well as the composition of actors involved. These characteristics of PPPs may make them also particularly vulnerable to corruption, even if a fair amount of literature refers to the general control-effect of private sector inclusion (e.g. Sclar 2000).

Hence, this article conceptualizes from a theoretical viewpoint the vulnerability of PPP models for governance problems stemming from unethical behavior and corruption against the backdrop of contract theory, principal-agent theory and transaction cost economics. Despite some of the „,channels "for these problems in PPPs resemble the ones regarding other forms public-private collaboration, due to the characteristics of PPPs, there are specific points that have to be highlighted (Klitgaard 2012).

The article's contribution to the ongoing debate on the use of PPPs therewith is twofold: first, an issue more or less neglected by the pertinent literature is analyzed theoretically. Second, tackling the question of the origins of unethical behavior and corruption in PPPs is all the more relevant as these instruments are used not only in developed countries whose legal order may shield PPPs sufficiently against corruption, but also in developing countries and emerging markets that do not provide these legal instruments. Hence, carving out the vulnerable points in PPP arrangements may not only rise awareness regarding this problem, but also may enable decision makers to install appropriate control mechanisms, if need be on project level.

\section{Public Private Partnerships}

Budgetary restraints and the pressure on public goods, particularly on existing network infrastructures led to a redefinition of the private and the public sphere and responsibilities in many countries. Private sector inclusion is discussed as a potential solution for the altering challenges of the public sector. This inclusion can take place in different guises - as full or partial privatization, or as joint projects in the form of public private partnerships (PPPs) between the public administration and private firms that ensure adequate control rights for the public sector over the crucial aspects of service provision (Demuijnck and Ngnodjom 2011; Marques and Berg 2011). PPPs constitute an 
"alternative to contracting out and privatization, and thus they are seen as a qualitative jump ahead in the effort to combine the strong sides of the public sector and the private sector" (Hodge and Greve 2007, p. 545). They also provide an opportunity in the sense of "entrepreneurial government movement" (Bloomfield 2006), as they do not only rely on private resources, but also market-oriented strategies with regards e.g. on competition and performance contracting. Generally spoken, the implicit assumption of a better value for money in PPPs is derived from the neo-classical view of markets under perfect information, even if empirical evidence for their superior performance remains limited (Hodge and Greve 2007; Reeves 2008).

Focusing on the opportunities of this form of cooperation, PPPs have some historical pedigree, but the theoretical analysis of these ,new “partnership models remains poor, and the term "PPP" itself is still lacking a precise, widely acknowledged definition (Hodge 2006). Neither being hierarchies nor markets, but something in between, they are relational arrangements based on contracts, but also on trust and (long-term) commitment (Mörth 2009). Hierarchy is replaced, and only a limited delegation of authority between the partners is given, raising questions regarding accountability (Behn 2001; Koenig-Archibugi 2004). These characteristics constitute a relevant distinction against other contractual arrangements (see e.g. Savas 2000). Hence, the prevalent PPP definitions typically focus either on the players involved or on procedural aspects of these partnerships (Bloomfield 2006; Grimsey and Lewis 2005; Marques and Berg 2011; Hodge and Greve 2007). Based on these theoretical approaches, PPPs in the sense of the presented study are contractual agreements between at least one private enterprise and the public sector that comprise more than one valueadded step or level - i.e. planning/project development, construction, management, operation and maintenance, as well as reconstruction (or removal) - of the respective project. This multi-step approach of PPPs, an equivalent to traditional bundling of tasks at the government's site, is the most relevant distinction versus other forms of public cooperation with the private sector, e.g. outsourcing/public procurement. Moreover some control rights remain with the public partner, while the private company enjoys some leeway to generate cash flow. Consequently, a complete material privatization cannot be classified as PPP. The duration of PPP projects varies between one and thirty years, with mere service and management contracts being of relatively short-term duration, while PPP designs which include the construction of an asset and that are refinanced by user fees are usually based on longer contract durations. In particular, long-term PPPs, which may involve several generations of civil servants, but also private managers and citizens, receive specific attention, as the concept of action and liability may be affected in these cases (Bloomfield 2006).

The commercial risk of failure is mainly borne by the public sector in (short-term) projects that do not affect the ownership of the asset (which remains with the public sector). In PPPs where a direct contact between the private company and the customer/ user exists (i.e. concessions and the Build-Operate-Transfer/Build-Own-Operate/BuildOwn-Operate-Transfer PPP variants), the private partner has to shoulder the main or at least a high portion of the commercial risk (Iossa and Martimort 2014). This is caused by potentially insufficient revenues relative to its costs (high upfront costs must be refinanced over extended periods of time), while protection mechanisms designed to reduce the commercial risk to the private company by guaranteeing a fixed or minimum revenue stream are not always in place. Generally, the number of contingencies 
regulated by the respective contract differs amongst countries and sectors, respectively (Iossa and Martimort 2014). Hence, even if the commercial risk can be fixed in the contract, in particular in developing countries proper enforcement mechanisms are often missing, or the inclusion of such clauses depends on the bargaining power of the private firm that may be limited. Overall, issues as risk allocation, risk management and, consequently, renegotiations, are the main impediments to the successful use of PPPs (see Carbonara and Pellegrino 2018; Pellegrino et al. 2013; Osei-Kyei and Chan 2015).

The expectations and interest - as well as the incentives - related to the socioeconomic outcomes of PPPs differ substantially among participants and stakeholders. Nonetheless, valuing PPPs as cooperations does not cannibalize their contractual nature that is based on different interest. As Markovits (2004) argues, "promises generally, and contracts in particular, establish a relation of recognition and respect - and indeed a kind of community - among those who participate in them [...] even though contracts typically arise among self-interested parties who aim to appropriate as much of the value that contracts create as they can" (Markovits 2004).

The public partner focuses on its need to procure additional capital as well as to attract managerial competences and technical skills - which are of special relevance in the case of technologically complex infrastructures like water supply, sewage systems, energy, and telecommunications - without losing the political control over infrastructure provision. Even if the evidence of higher efficiency in the private sector is not unquestioned in literature, in fact the private company may be more accountable to its customers and to the public partner due to the existence of a contract that defines duties and potential penalties, and the service delivery is expected to be better (Marques and Berg 2011). Additionally, as many forms of PPPs allow the financing of the public infrastructure as off -budget or off-balance-sheet, at least the public perception is given that these models avoid new debt (Bloomfield 2006; European PPP Expertise Center (EPEC) 2014). This fact may be more relevant for the political level that decides whether PPPs are principally an option of service provision, less important for the administration.

As for the administrative level, the expectations regarding to the implementation of PPPs may differ. Beyond the expected benefits - which in the long term also may enlarge the leeway of the administration in the sense of Niskanen (1971) - there are at least short-term restrictions or inconveniences arising from PPPs. The administrative level has to cope with new (prospective) partners, most likely new legal regulations for tendering the PPP, and possibly the public that has a stake in the respective project. An increased workload or the necessity of further training may be the consequence - in particular for smaller administrative bodies a challenge that is not easy to manage. The implicit assumption that the public partner may have a homogeneous interest therefore has to be questioned. This fact becomes relevant in the context of corrupt behavior, as the drawbacks coming from PPPs may increase the single civil servant's impulse to be open towards bribes and corruption.

In contrast, the private company is driven by profit motives (Reeves 2008). In addition to maximizing its profit in the specific projects at stake, the private partner typically pursues a long-term, strategic goal, too: experience and expertise in one country as a PPP partner may increase the likelihood of winning future tenders for similar PPP projects in other contexts, which is of interest in particular for multinational enterprises. 


\section{Unethical Behavior and Corruption as Governance Problems in PPPs}

With a view to the broad range of actions and measures that can be classified as "unethical behavior" like e.g. nepotism, or ,corruption "in the context of PPPs, political, socio-economic or more philosophical perspectives on this topic are of interest (see e.g. Caiden and Caiden 1977). As the constituent factor in the author's definition, the - mostly clandestine - use of assigned power for private gains clearly stands out, whether by government officials or other individuals (von Arnim et al. 2006). This fact is even more relevant as - in the context of the economic theory of new institutional economics - in all cases of assigned power some kind of principal-agent-relationship exists. A principal, who delegates power, and an agent, who wields that power, but whose actions cannot be supervised by the principal, characterize such a situation. This is true even though not all kinds of violations of obligations that occur due to principalagent-problems can be characterized as being unethical or corruption.

The implicit assumption is that there is a societal consent regarding the acceptable set of actions, and a clear-cut understanding of where misuse of authority or assigned power starts (Caiden and Caiden 1977). This definition covers a broad range of actions, independent from the question if, or if not, the individual act is liable to prosecution in a specific context. This broad approach is necessary as the legislation as well as the general attitude towards corruption differs substantially across countries: while in most countries worldwide bribery is illegal, prosecution schemes differ, and so does the perception of unethical behavior. Hence, even if a specific act - e.g. the distortion of the tendering process in favor of an enterprise the public official may be linked to - is socially accepted, it causes the negative effects associated to corruption. Accordingly, also non-criminal actions can be understood as corruption in the sense of this study, as long as they lead to unfavorable outcomes in terms of inefficient allocation of bids, inefficient service delivery or increased cost levels for the public sector.

Moreover, these practices often can occur as network corruption in the sense that a relatively closed social network benefits from the corrupt practice, not only a single individual. Actions that - directly or indirectly - improve one's position within the social network are undertaken (von Arnim et al. 2006). Here, often a time lag exists between the corrupt practice and the benefit from it: The investment occurs at $t_{1}$, while the return on investment (RoI) occurs in $t_{1}$ or $t_{2}$ or even later (Priddat 2005).

Based on insights from principal-agent theory and contract theory the vulnerability for unethical behavior in PPPs can be grounded on three characteristics: the very incomplete and somewhat discretionarily decided contract with high transaction costs they are based on, the multi-level characteristics of implementation and execution, as well as the underlying multi-step or life-cycle concept. This vulnerability may realize in different specific channels for unethical behavior and render them more to this behavior than other contractual agreements or collaborations between the private and the public sector (Hemming 2014; Iossa and Martimort 2014; Klitgaard 2012). Incentives as well as possibilities to behave like this are induced by these characteristics.

Assuming that individuals have no implicit preference towards more or less ethical behavior, their decision will depend on the incentive in a specific situation and the expected costs - including transaction costs - and benefits from their decision. Consequently, for both sides - the "briber" and the "bribe" - unethical behavior can be modelled as a revenue function. The underlying assumption is that the private side has 
an incentive to bribe the public servant (not vice versa). While the decision to implement a partnership with the private sector is a political one (pre-tender decision), the tendering and execution process itself is guided by the administrative level (ex ante as well as ex post to the project execution). Hence, one can assume that in most cases the receptor side for corruption will be on the public side: The political level may be the subject of bribery in the pre-tendering phase, with enterprises trying to influence politicians to open up sectors for PPPs, or more concretely, to turn a single project into a PPP. The administrative level will be the target whenever a private enterprise strives for becoming part of a newly established PPP, as the public administration allocates the right (which is often a monopoly) of serving the market. The same applies to corruption in the execution phase of the project or after completion (in the context of re-negotiations or contract renewal).

For the briber, the private enterprise, the revenue stems from the cash flow of the project - may it be the direct payment by the public sector, user fees, or a mixed approach. The costs of the PPP include not only the implementation or service costs (depending on the PPP type), but also transaction costs and the costs of paying the bribe, as well as additional costs from the discovery of corruption (punishment costs, e.g. loss of reputation or the penalty multiplied by the probability of discovery). The incentive for corruption is given when the revenues outperform the costs. Hence, corruption is likely when under corruption the cash flow from the project is higher or the implementation- or service costs may be lower (e.g. due to reduced quality standards, overpricing of the users or underinvestment).

For the politician as well as public servant, the decision to become corrupt can be modelled similarly. The bureaucrat is likely to accept benefits if the expected benefit/ revenue (that may be higher or lower than the costs of corruption of the private partner and may be subject to discounting if the pay-off is in the future, e.g. a position in the board of a private company for a politician) are higher than the expected penalty or opportunity costs (dismissal or loss of pension) times the probability of being caught.

The revenue stream as well as the costs related to corruption are endogenous to the respective project, even if they may differ substantially amongst projects, depending on the PPP-type, the specific contract design as well as the financial size of the project, while the probability of being caught is exogenous to the specific project.

Table one summarizes the characteristics of PPPs that may be relevant in the context of unethical behavior and corruption and are directly related to the multi-level characteristics of implementation and execution, the somewhat discretionarily decided incomplete contract they are based on, as well as the inherent multi-step or life-cycle concept (Table 1).

\section{Incomplete Contracts and Transaction Costs}

PPPs typically emerge in a context of incomplete information and uncertainty, contracts will - necessarily - be incomplete (Parker and Hartley 2005). The physical nature of the network, uncertainty regarding future use as well as the likelihood of specific external "shocks" remain unclear at the time the contract is fixed. Even if contingent clauses can be applied, their use imposes requirements - possibly realized events have to be anticipated, described and verified - that are not easy to fulfil (Iossa and Martimort 2014). All measures, undertaken by one or both contract parties to overcome 
Table 1 PPP Characteristics and Unethical Behavior

\begin{tabular}{|c|c|c|c|}
\hline & pre-level & ex ante & ex post \\
\hline Subject & Political level & Administration & Administration \\
\hline Taks/Decision & $\begin{array}{l}\text { PPP or other forms of provision } \\
\text { (public only, outsourcing etc.) }\end{array}$ & $\begin{array}{l}\text { - PPP-Model } \\
\text { - Contract details } \\
\text { - Private partner }\end{array}$ & $\begin{array}{l}\text { - Renegotiations? } \\
\text { - Application of penalty } \\
\text { clauses? } \\
\text { - Change of contract } \\
\text { contents }\end{array}$ \\
\hline $\begin{array}{c}\text { Channel for } \\
\text { unethical } \\
\text { behavior }\end{array}$ & $\begin{array}{l}\text { - Discretion } \\
\text { - Lack of transparency }\end{array}$ & $\begin{array}{l}\text { - Discretion } \\
\text { - Lack of transparency } \\
\text { - Information } \\
\text { asymmetry } \\
\text { - Transaction costs }\end{array}$ & $\begin{array}{l}\text { - Lack of transparency } \\
\text { - Contract incompleteness } \\
\text { - Information asymmetry } \\
\text { - Transaction costs } \\
\text { - Hold-up situation }\end{array}$ \\
\hline $\begin{array}{l}\text { Possible } \\
\text { consequences }\end{array}$ & $\begin{array}{l}\text { - Market distortion } \\
\text { - Inefficient resource allocation } \\
\text { - Space for inefficiencies in later } \\
\text { stages of the PPP-project }\end{array}$ & $\begin{array}{l}\text { - Dysfunctional } \\
\text { competition for the } \\
\text { market } \\
\text { - Suboptimal choice of } \\
\text { PPP-type } \\
\text { - Choice of inefficient } \\
\text { partner/s-best solu- } \\
\text { tion }\end{array}$ & $\begin{array}{l}\text { - Overpricing of users or } \\
\text { the public sector } \\
\text { - Additional transaction } \\
\text { costs for the public } \\
\text { sector } \\
\text { - Loss of service } \\
\text { quality/- } \\
\text { underperformance }\end{array}$ \\
\hline
\end{tabular}

Source: Author's compilation

that incompleteness "give rise to correspondingly high transaction costs" (Dudkin and Timo Välilä 2007). With a view on the transaction cost theory, developed by Coase (1937) and Williamson (1975/1985), transactions - such as the transfer of property rights - can never be realized free of cost. Transaction costs therefore are all costs which occur in the context of contract formation, monitoring or enforcement, including information costs and the costs of the creation of institutions necessary for contract supervision (Blum et al. 2005). These costs, arising from the incompleteness of the contract, increase the total costs of the deal. They are of specific importance when opportunistic behavior - "the incomplete or distorted disclosure of information, especially the calculated effort to mislead, distort, disguise, obfuscate or otherwise confuse" (Williamson 1985) - is to be expected, which also must be taken care of in the contract (see e.g. Erlei et al. 2007). The exploitation of information asymmetry can also be categorized as opportunistic behavior - with the danger of opportunism increasing with asset specificity (Reeves 2008).

These costs occur at each stage of the PPP; corruption can therefore be helpful to reduce these costs - for the private, but also for the public partner: successful corruption creates a kind of hold-up situation to the disadvantage of the public partner, as - in the sense of modern national states' enabling and guarantor role in the provision of services - the public employee is tied to the private enterprise. As a consequence, and knowing that any service interruption will result in additional problems, the incentive to make concessions can be assumed to be higher than in other contractual arrangements. In addition, through upstream-corruption potential problems in the future can be smoothened - a fact which also becomes relevant if the tender process itself was completed without corruption, as for future projects, contract renewals or re-negotiations the RoI 
may be high enough. At the same time, also for the public partner corruption may be useful as - being tied together through corruption - the public partner's risk of becoming a victim of later re-negotiations may be lowered.

\section{Multi-Level Characteristics}

Even if many scientific studies tackle the pre-level, the political decision in favor of a PPP, or the level ex ante to the implementation of the PPP, the tender process itself, the post-tender stage has been widely ignored so far, as well as the potential problems arising from the PPP-inherent multi-level characteristics (Iossa and Martimort 2011).

At the first, the pre-decision level, politicians decide to turn a specific infrastructure project into a PPP. As evidence demonstrates that in general corruption may lead to misallocation of resources, e.g. in favor of sectors with a higher potential to be "bribegenerating", it is likely that the same effect may take place in the context of PPPs (Liu and Mikesell 2014). From the firm's viewpoint, corruption in this first stage of the PPPprocess is characterized by a high risk, while the outcome remains insecure. Caused by the multi-level characteristics of PPPs, even if the respective political decision has been (successfully) influenced in favor of the PPP-alternative, there is no certainty that the enterprise itself will be the private partner in the project. Nonetheless, corruption at this level may be useful from the firm's viewpoint if the expected benefit is high enough (in particular multi-step PPPs with a large financial volume that include operation and ownership may be affected here, similar to experience from sheer privatization projects, see e.g. Sclar 2000; Savas 2000).

As for all kinds of PPPs, the tender process is of pivotal relevance, with being quite similar to more general forms of public procurement (and therefore extensively covered by literature, e.g. Sclar 2000; Savas 2000; Iossa and Martimort 2011). As delineated above, in the ex ante and ex post stage, the administration is the decision-maker, implementing and managing PPPs, and consequently the second stage with regard to corruption. Corrupt behavior can take place at this stage independently of previous corruption on the political level, even if there may be an amplifying effect: once an enterprise paid bribes to turn a specific project into a PPP, the misunderstanding of "sunk costs" may lead to corruption at this later stage.

In most countries, e.g. in the member states of the EU, formal public procurement law has to be applied before a PPP can be established, similar to other forms of contracting out. While this fact diminishes to a certain degree the implicit idea of innovation in PPPs, which should not be affected by a large number of regulations, on first sight it may also shield partnerships against unethical behavior (Bloomfield 2006). Per se there is no chance to bypass existing public procurement laws with the implementation of a PPP, at least in more developed countries. This also is the case for unsolicited offers by private companies without a prior tender process (see for details Hodges and Dellacha 2007). Accordingly, the selection of the private partner is most of the time the endpoint of a two-tier decision-making process. Within this process, a competition for the market, private companies make their bids to win the contract.

For all enterprises that are involved in public procurement contracts in general, this stage of the decision-making process is of pivotal interest, as it is characterized by both - high risk and substantial cost drivers - while the outcome still remains insecure. The 
search for tender information, specific information about the planned project, the preparation of the offer itself, and the provision of sufficient proofs of suitability are relevant for success in the bidding process, but costly. Payments for insider information or an inclusion in the list of pre-qualified bidders may pay off here, as well as to influence the structure of the bidding specifications so that the enterprise is the only qualified supplier (Cobarzan and Hamlin 2005). The private enterprise also may influence the PPP-model chose as well as contracting details - both aspects that are relevant for the long-term RoI as well as for the service quality and quantity and therewith the public interest in the project. As for the public sector, the specification of the services in question, the contract outline as well as the examination of and the decision on the biddings are of specific relevance. Additionally, and before the tender process can be started, a project-specific suitability test has to be undertaken whether the project can be efficiently managed as a PPP.

As all these steps give rise to high transaction costs, corruption within this stage therefore seems to be especially worthwhile for both parties, reducing their costs, and may thus be more likely to occur than during the later stages. Discretion is a key to corruption in this context as well, in particular if accountability is limited - e.g. due to limited transparency - and monopolies are affected (Klitgaard 2012). This is all the more true as the detection probability can be valued as relatively low, as the contract typically is kept confidential, and little transparency exist on the contingencies that trigger monetary compensations to the contractor or even on the amounts paid" (Iossa and Martimort 2014) - neither ex ante nor ex post. Hence, only the two contract parties have the complete information on and overview over the contract. This fact increases the incentive and therewith opens the door for the private enterprise to manipulate the bidding process by corruption, as it is unlikely that corrupt behavior will be detected by a third party external to the deal. Transparency, a very relevant instrument of control for the public as well as the losing bidder - therefore is missing. Accordingly, the options for the latter to take legal action are limited. Another problem in this context is the fact that bidding cartels are not the exception, in particular in those infrastructures where an oligopolistic market structure exists, so that inefficient allocation may lead to monopoly rents for the winning enterprise, increasing the RoI and therewith the incentive for corruption (Andres et al. 2008).

In the execution phase of the PPP, ex post to contracting, particularly a long contract duration can be relevant with regard to the likelihood of corruption. Enterprises may underinvest or under-maintain, the users may be overcharged or provided with low service quality, and cover their underperformance with bribes (Estache 2014). This may be in particular relevant with a view to contract re-negotiations, which occur in most cases (Marques and Berg 2011). Corruption in this phase may cover the underperformance, so that a successful contract renewal is possible - the investment in corruption will ceteris paribus yield a high RoI as the cash flow from the project can be expected to be supra-normal if the conditions of the private firm will be accepted by the public partner.

\section{Life-Cycle Approach}

The life-cycle approach contributes in two ways to the increased vulnerability of corruption: one important strand of incentives results in the fact that the different 
value-added steps included in a PPP will result in high project volumes, so that the direct costs of corruption are likely to be lower than the expected return on investment (RoI). At the same time, in particular with a view to the long contract period and to the fact that most PPP contracts have to be renewed after the first contract period has ended, the investment in corruption will ceteris paribus yield a high RoI, as the cash flow from the project can be expected to be supranormal if the conditions of the private firm will be accepted by the public partner (Klitgaard 2012; Marques and Berg 2011). Hence, following the decision logic delineated above, for the private enterprise the incentive for corruption is high.

Moreover, the longer a cooperation lasts, the higher the risk of reciprocal personal advantage, as mutual trust and understanding grow over time (Sack 2004). This fact is of relevance as reputation and trust are of pivotal importance when it comes to the reduction of transaction costs of corruption (Parker and Hartley 2005). The incentive to behave opportunistically will be lower over time, as the gains from trust will be increasing successively (Erlei et al. 2007). The longer the contract lasts, the higher the probability that the benefits from trust will exceed the benefits from opportunistic behavior; reputation and trust become a kind of social capital, which accumulates with further use; Parker and Hartley 2005). Therefore, the risk of treason decreases with the contractual period that has already past. Accordingly, the likelihood of corruption increases in long-term cooperations, as the individuals' risk decreases - knowing the partner better, being bound by trust increases the likelihood to give/take the bribe. In this context, in particular corruption that is designed to assure the successful recontracting is of relevance: The payment occurs during the first contract period, while the benefits materialize in the second period. Additionally, corruption to enforce renegotiations of the contract in favor of the private enterprise during the contract period are to be expected at this point, e.g. with a view to an increase of tariff rates or a decrease of quality standards. This may especially be the case in markets which are characterized by intense competition, where the initial bidding has to be low in terms of fees or tariffs.

\section{Conclusion and Policy Recommendations}

Based on the gateways outlined above, the implementation of PPPs may be affected by governance problems, either anticipated ex ante or ex post. First, the overall efficiency of the project is on the trail at least once corruption takes place: the alleged increase in cost efficiency of PPPs - per se questionable, for being nearly impossible to assess ex ante -, compared to traditional public provision, must not be offset by the costs of corruption (Flyvbjerg et al. 2002). As delineated above, increasing transaction costs, or a decreasing value for money of the project may be the consequence, and therewith a substantially lower likelihood that a specific project can be run more efficiently as a PPP than via public procurement. This would not only diminish the expected benefits from PPPs, but can also lead to increased costs compared with the status quo ante.

Second, and closely related to the first point, competition may be distorted: if the private enterprise is able to suppress the market mechanism through successful corruption, it becomes a price maker instead of being a price taker, relatively similar to the classic monopoly situation, even if it could not exist in a competitive 
environment (Priddat 2005). Hence, corruption can render an inefficient bidder the successful, winning bidder - a special form of adverse selection. Depending on the details of the PPP design, this inefficiency may result not only in additional costs for the public partner (when the payment is fixed) or non-optimal prices for the consumers, e.g. in all concession models, but also may lead to ineffective service provision.

Lastly, nepotism or corruption comes to the disadvantage of "weak interest" in the public sector (Sack 2004): as through PPPs the existing principal-agent problems can be modified in the sense that - due to asymmetric information and fiscal leeway political or public interest becomes less important than the business interests of the oligopolistic market players. Biased PPP regimes therefore act as a kind of monopolization of semi-open market situations (Priddat 2005). This problem becomes even more obvious because merely the public partner is bound by public law and political rationales, which do not apply to the private enterprise. Accountability in the traditional sense is not given in these cases; again, disadvantages for the public interest may be the result.

Nonetheless, PPPs became an important instrument of the public sector to finance and manage much-needed infrastructure and services over the last decades. Independent of the potential gains out of these cooperations, specific challenges may arise that may compromise not only the long-term success of these partnerships, but also may make them less desirable - in terms of efficiency and effectiveness - compared to the status quo ante. Unethical behavior and corruption may be amongst all the most challenging, but only marginally noted factors in this context.

Several factors can be identified that help to control these governance problems, in particular the proper combination of monitoring and punishments (Becker and Stigler 1974). They tackle the exogenous dimension, increasing the likelihood of exposure, not the project-inherent dimension of direct costs or revenues. Increased transparency, regardless of whether it is enforced due to changes in the legal framework, or due to public attention, is one crucial issue in this context. This applies to both levels, the political as well as the administrative level. Decreasing the "discretion of contracting authorities by making greater use of centrally determined guidelines on contracts" (Iossa and Martimort 2014) also may reduce corruption at the ex ante and ex post level, as well as audit based on performance, specific whistle-blower programs or job rotations and the broad use of the "four eyes principle".

Quite similar effects can be induced by an increase of the costs of specific, unwanted behavior through higher penalties (for public as well as private actors) if such a practice is discovered - both with respect to penalties and imprisonment. Also payments schemes for the public administration matter in this context: If life-long career systems in the public sector are no longer existent or obtaining lifelong employment becomes unlikely for the individual in a specific position, the risk of corruption will be substantially higher compared to the status quo ante.

Overall, the specific vulnerability for corruption can be seen as inherent to the PPP system, and is therefore not easy to erase. The proposed measures to reduce the risk of unethical behavior in the context of PPP implementation therefore can never eliminate it totally, but can increase the costs and/or lower the benefits; they might therefore reduce it in the long run, starting by changing the parameters of decision-making of individuals. 
Funding Information Open access funding provided by Carinthia University of Applied Sciences (CUAS).

\section{Compliance with Ethical Standards}

\section{Conflict of Interest none.}

Informed Consent none.

Ethical Approval none.

Open Access This article is licensed under a Creative Commons Attribution 4.0 International License, which permits use, sharing, adaptation, distribution and reproduction in any medium or format, as long as you give appropriate credit to the original author(s) and the source, provide a link to the Creative Commons licence, and indicate if changes were made. The images or other third party material in this article are included in the article's Creative Commons licence, unless indicated otherwise in a credit line to the material. If material is not included in the article's Creative Commons licence and your intended use is not permitted by statutory regulation or exceeds the permitted use, you will need to obtain permission directly from the copyright holder. To view a copy of this licence, visit http://creativecommons.org/licenses/by/4.0/.

\section{References}

Andres L, Azumendi SL., and Guasch JL (2008) Regulatory Governance and Sector Performance: Methodology and Evaluation for Electricity Distribution in Latin America. Policy research working paper 4494. World Bank.

Becker, G. S., \& Stigler, G. J. (1974). Law enforcement, malfeasance, and compensation of enforcers. The Journal of Legal Studies, 3, 1-18.

Behn, R. (2001). Rethinking democratic accountability. Washington: Brookings Institution.

Bloomfield, P. (2006). The challenging business of long-term public - Private partnerships: Reflections on local experience. Public Administration Review, 66(3), 400-411.

Blum U, Dudley L, Leibbrand F, and Weiske A (2005) Angewandte Institutionenökonomik: Theorien Modelle - Evidenzen. Wiesbaden: Gabler.

Caiden, G. E., \& Caiden, N. J. (1977). Administrative corruption. Public Administration Review, 37(3), 301309.

Carbonara, N., \& Pellegrino, R. (2018). Revenue guarantee in public-private partnerships: A win-win model. Construction Management and Economics, 36(10), 584-598.

Coase RH (1937) The nature of the firm, Economica, New Series, 4, 16: 386-405.

Cobarzan, B., \& Hamlin, R. E. (2005). Corruption and ethical issues regarding public private partnerships. Revista Transilvană de Ştiințe Administrative, 3(15), 28-37.

Demuijnck, G., \& Ngnodjom, H. (2011). Public-private partnerships and corruption in developing countries: A case study. Business \& Professional Ethics Journal, 30(3-4), 253-268.

Dudkin G and Timo Välilä T (2007) Transaction costs in public private partnerships: A first look at the evidence. European Investment Bank Economic and Financial Report 2005/03. Luxemburg.

Erlei, M., Leschke, M., \& Sauerland, D. (2007). Neue Institutionenökonomik (2nd ed.). Stuttgart: Schäfer Poeschl.

Estache A (2014) Infrastructure and corruption: A brief survey, ECARES Working Paper 2014-37.

European PPP Expertise Center (EPEC) (2014) Eurostat treatment of public-private partnerships purposes, Methodology and Recent Trends, EIB working paper. https://www.ppp.worldbank.org/public-privatepartnership/sites/ppp.worldbank.org/files/documents/Eurostat\%20Treatment\%20of\%20PPP.pdf. Accessed 15 Oct 2019.

Farazmand, A. (1999). Globalization and public administration. Public Administration Review, 59(6), 509-522.

Farazmand, A. (2002). Globalization, privatization, and the future of modern governance: A critical assessment. Public Finance \& Management, 2(1), 151-186.

Flyvbjerg, B., Skamris Holm, M., \& Buhl, S. (2002). Underestimating costs in public works projects: Error or lie? Journal of the American Planning Association, 68, 279-295. 
Grimsey, D., \& Lewis, M. K. (2005). Introduction. In D. Grimsey, \& Mervyn. K. Lewis (Eds.), The economics of public private partnerships the international library of critical writings in economics 183, xiii-xl. Cheltenham/Northhampton: Edward Elgar.

Hemming, R. (2014). Public-private partnerships, government guarantees, and fiscal risk. Washington: International Monetary Fund.

Hodge, G. (2006). Public private partnerships and legitimacy. UNSW Law Journal, 29(3), 318-327.

Hodge, G. A., \& Greve, C. (2007). Public-private partnerships: An international performance review. Public Administration Review, 67(3), 545-558.

Hodge, G. A., \& Greve, C. (2010). Public-private partnerships: Governance scheme or language game? Australian Journal of Public Administration [P], 69(1), 8-22.

Hodges JT and Dellacha G (2007) Unsolicited infrastructure proposals - How some countries introduced competition and transparency. PPIAF Working Paper 1, http://www.ppiaf.org/ppiaf/sites/ppiaf. org/files/publication/WP1-Unsolicited\%20Infra\%20Proposals\%20-\%20JHodges\%20GDellacha.pdf

Iossa E and Martimort D (2011) Post-tender corruption and risk allocation, implications for public-private partnerships. CEIS Research Paper 195. ftp://www.ceistorvergata.it/repec/rpaper/RP195.pdf.

Iossa E and Martimort D (2014) Corruption in PPPs, incentives and contract incompleteness. IEFE - The Center for Research on Energy and Environmental Working Paper 67.

Klitgaard R (2012) Public-private collaboration and corruption. In: Pieth, M Collective Action: Innovative Strategies to prevent Corruption. Basel: Basel institute on governance: 41-66.

Koenig-Archibugi, M. (2004). Transnational corporations and public accountability. In D. Held \& M. KoenigArchibugi (Eds.), Global governance and public accountability (pp. 110-135). London: Blackwell Publishing.

Kwak, Y. H., Chih, Y. Y., \& Ibbs, C. W. (2009). Towards a comprehensive understanding of public private partnerships for infrastructure development. California Management Review, 51(2), 51-78.

Liu, C., \& Mikesell, J. L. (2014). The impact of public officials' corruption on the size and allocation of U.S. state spending. Public Administration Review, 74(3), 346-359.

Markovits, D. (2004). Contract and collaboration. The Yale Law Journal, 113(1417), 1419-1519.

Marques, R. C., \& Berg, S. (2011). Public-private partnership contracts: A tale of two cities with different contractual arrangements. Public Administration, 89(4), 1585-1603.

Mörth, U. (2009). The market turn in EU governance-The emergence of public-private collaboration. Governance: An International Journal of Policy. Administration, and Institutions, 22(1), 99-120.

Niskanen, W. A. (1971). Bureaucracy and representative government. Chicago: Aldine Atherton.

Osei-Kyei, R., \& Chan, A. P. (2015). Review of studies on the critical success factors for public-private partnership (PPP) projects from 1990 to 2013. International Journal of Project Management, 33(6), 1335-1346.

Parker D and Hartley K (2005) Transaction costs, relational contracting and public private partnerships: A case study of UK defence. In: Grimsey D and Lewis MK (eds) The Economics of Public Private Partnerships. The international library of critical writings in economics 183, Cheltenham/Northhampton: Edward Elgar, pp. 303-314. Also published in Journal of Purchsing \& Supply Management 9: 97-108.

Pellegrino, R., Vajdic, N., \& Carbonara, N. (2013). Real option theory for risk mitigation in transport PPPs. Built Environment Project and Asset Management, 3(2), 199-213. https://doi.org/10.1108/BEPAM-052012-0027.

Priddat B (2005) Schwarze Löcher der Verantwortung: Korruption Die negative Variante von Public-Private Partnership“ in Jansen SA and Priddat B (ed) Korruption: Unaufgeklärter Kapitalismus Multidisziplinäre Perspektiven zu Funktionen und Folgen der Korruption. Wiesbaden: VS: 85-102.

Reeves, E. (2008). The practice of contracting in public private partnerships: Transaction costs and relational contracting in the Irish school sector. Public Administration, 86(4), 969-986.

Sack D (2004) PPP im aktivierenden Staat" (Presentation at the conference "Stand und Perspektiven der politikwissenschaftlichen Verwaltungsforschung", September 23rd-25th, Koblenz 2004: Deutsche Vereinigung für Politische Wissenschaft (DVPW)).

Savas, E. S. (2000). Privatization and public-private partnerships. New York: Chatham House.

Sclar, E. D. (2000). You Don't always get what you pay for. The Economics of Privatization. Ithaca: Cornell University Press.

von Arnim HH, Heiny R and Ittner S (2006) Korruption. Begriff, Bekämpfungs- und Forschungslücken, FÖV Discussion Papers 33. Speyer: Deutsches Forschungsinstitut für öffentliche Verwaltung Speyer.

Williamson, O. E. (1975). Markets and hierarchies: Analysis and antitrust implications, a study in the economics of internal organization. New York: Free Press.

Williamson, O. E. (1985). The economic institutions of capitalism. Cambridge and New York: The Free Press. 
Publisher's Note Springer Nature remains neutral with regard to jurisdictional claims in published maps and institutional affiliations.

Rahel M. Schomaker holds a Professorship for Economics and Public Administration at the CUAS Villach, and is affiliated with the German University of Administrative Sciences Speyer and the German Research Institute for Public Administration. After graduating in Business Administration, Political Science, Economics and Middle Eastern Studies in 2004, Dr. Schomaker received her PhD (with honors) from the University of Muenster in 2009, completed her Habilitation in 2012 in Speyer, and was a professor for Economics at the CBS Cologne. She works as a consultant for national and international administrations, in particular in the Middle East and the Black Sea region. Her research focuses on Administrative Change, Formal and Informal Public Sector Cooperations and Networks, Governance and Trust. 